\title{
Przegląd technik inwentaryzacji rury szybowej
}

\author{
Mateusz Jabłoński, Wojciech Jaśkowski \\ AGH Akademia Górniczo-Hutnicza, Wydziat Geodezji Górniczej i Inżynierii Środowiska, \\ Katedra Ochrony Terenów Górniczych, Geoinformatyki i Geodezji Górniczej, \\ e-mail:jablon@agh.edu.pl,jaskow@agh.edu.pl
}

Streszczenie: Nadrzędnym celem pomiarów i obserwacji wykonywanych w szybach jest zapewnienie ich bezpiecznej pracy. Wiąże się to nie tylko z określeniem aktualnego stanu technicznego szybu, lecz również z określeniem przyczyn i źródeł powstawania zmian. Wraz z rozwojem technik laserowych i cyfrowych pojawiają się nowe możliwości prowadzenia bezpiecznej inspekcji i inwentaryzacji wyrobisk szybowych. W celu zachowania sprawności szybu wykonuje się szereg prac inwentaryzacyjnych, opisanych szczegółowo w Rozporządzeniu Ministra Gospodarki z dnia 28 czerwca 2002 i jego załączniku (nr 4) [1,2]. Artykuł przedstawia przegląd technik pomiarowych stosowanych obecnie do pomiarów deformacji rury szybowej, ze szczególnym uwzględnieniem ciągłych telemetrycznych metod pomiarowych.

Szczegółowo opisano zaprojektowany dla Kopalni Soli 'Wieliczka' system monitoringu wykorzystany w latach 2014 i 2015 podczas wykonywania iniekcji usztywniających i uszczelniających szyb Kościuszko. W celu uniknięcia uszkodzeń konstrukcji szybu oraz awarii krytycznych skonstruowano i zainstalowano mobilny system monitorowania stanu szybu. Wyniki jego pomiarów pozwoliły wskazywać w czasie rzeczywistym zmiany, a w razie konieczności dokonywać modyfikacji przebiegu iniekcji i w sytuacjach awaryjnych wstrzymać proces. Analiza rezultatów wykazała niewielkie deformacje obudowy szybu podczas iniekcji oraz jednoznacznie potwierdziła zalety wykonanego systemu monitoringu i nowatorskiego sposobu iniekcji wysokociśnieniowych.

Słowa kluczowe: telemetria, rura szybowa, inwentaryzacja.

\section{Wstęp}

Szyb górniczy jest najważniejszym elementem podziemnej kopalni, to on determinuje możliwość jej działalności i sprawnej pracy. Z jego pomocą odbywa się transport ludzi, urobku i sprzętu oraz wentylacja podziemnych wyrobisk. Pozwala na szybką akcję ratunkową oraz zapewnia szybką ewakuację zagrożonych pracowników. Jednocześnie szyb, a w szczególności rura szybowa, poddawany jest zarówno wpływom natury geologicznej, jak i antropogenicznej. Składają się na to: lokalna struktura geologiczna (ukształtowanie tektoniki złoża), ruchy mas skalnych spowodowane eksploatacją górniczą, wody opadowe i gruntowe przenikające do szybu czy występujące wokół szybu pustki (niebezpieczne szczególnie w przypadku eksploatacji soli) [3].

W celu zapewnienia ciągłej sprawności szybu dział szybowy i mierniczy wykonują szereg czynności: od wizualnej oceny stanu obudowy szybu po obserwacje metryczne. Rzetelne prowadzenie okresowej inwentaryzacji i pomiarów w szybach ma zapobiec niszczeniu elementów uzbrojenia szybu i rury szybowej. Niezależnie od celu prowadzonej inwentaryzacji, należy brać pod uwagę kolejne cechy szybu [4]: 
- parametry konstrukcyjne szybu (kształt, obudowa, zabudowa szybu),

- długość rury szybowej,

- rodzaj zabudowy ciągu prowadniczego i innych urządzeń szybowych,

- przeznaczenie i funkcja szybu (wdechowy, wydechowy, transport ludzi, urobku),

- możliwości wykonywania pomiarów geodezyjnych i instalacji elementów systemów (np. dostęp do zrębu szybu, przedział drabinowy),

- czas przeznaczony na realizację pomiaru (inwentaryzacji).

Wyłączenie szybu z działalności na czas pomiaru generuje poważne straty w działalności zakładu. Uniemożliwia transport ludzi czy urobku oraz szybkie dotarcie do poszkodowanych $\mathrm{w}$ razie wypadku. Widoczne i naturalne jest więc dążenie do skracania czasu potrzebnego do wykonania inwentaryzacji. Ważnym jest, aby podczas tych czynności zapewnić również bezpieczeństwo osobie wykonującej te czynności. W tym celu rozwija się metody umożliwiające inwentaryzację rury szybowej oparte na laserowym (bezdotykowym) pomiarze odległości, metodach cyfrowych czy quasi-ciągłym monitoringu.

\section{Charakterystyka pomiarów geodezyjnych wykonywanych dla potrzeb inwentaryzacji rury szybowej}

Dobór metod zależy głównie od stanu szybu, prędkości zachodzących zmian i prognoz odnoszących się do innych działań w pobliżu szybu, np. eksploatacji w filarze ochronnym, iniekcji mających uszczelnić szyb czy pogłębiania szybu. Pozyskiwanie informacji na temat stanu rury szybowej i jej obudowy można zakwalifikować do dwóch zasadniczych grup: oceny wizualnej i obserwacji metrycznych [5].

\subsection{Ocena wizualna}

Ocena wizualna to inwentaryzacja widocznych zmian zewnętrznej struktury obudowy i elementów wyposażenia szybu. Obejmuje m.in. pęknięcia, odspojenia w strukturze obudowy, rysy i szczeliny, wycieki spoza obudowy. Dokonujący oceny obserwuje również elementy wyposażenia szybu, czyli stopień zużycia materiałów wskutek korozji czy gnicia oraz zerwania połączeń. Ocena prowadzona może być klasycznie przez dział szybowy i energomechaniczny lub z wykorzystaniem systemu monitoringu wizualnego opartego na kamerach cyfrowych.

\subsubsection{Klasyczna ocena wizualna}

Codzienna i okresowa ocena wizualna przeprowadzana jest przez dział szybowy i energomechaniczny Zakładu Górniczego. Częstotliwość i dobór metod oceny uzależnione są od rodzaju i przeznaczenia szybu. W szybach, gdzie istnieje tylko rura szybowa (bez uzbrojenia, zwykle szyby przeznaczone wyłącznie do wentylacji) inspekcje wykonuje się raz na kwartał (co 3 miesiące). Specjalistyczny Urząd Górniczy (Katowice), któremu podlegają szyby górnicze w całej Polsce, dopuszcza w ciągu roku trzykrotne wykorzystanie kamery i przynajmniej jedną rewizję wykonywaną wizualnie przez człowieka. W przypadku braku możliwości użycia maszyny wyciągowej w szybie należy wynająć wyciąg i zamontować skip z wyciągarką umożliwiając przejazd człowiekowi (np. na Górnym Śląsku wyciąg wypożycza się najczęściej z Centralnej Stacji Ratownictwa Górniczego w Bytomiu). W przypadku szybów ruchowych, gdzie zabudowany jest wyciąg szybowy, zgodnie z załącznikiem rozporządzenia [2] rewizje wykonuje się z częstotliwością podaną w tabeli 1. 
Tabela 1. Częstotliwość rewizji w szybach ruchowych wraz z określeniem wykonawcy

\begin{tabular}{lll}
\hline $\begin{array}{l}\text { Częstotliwość } \\
\text { rewizji }\end{array}$ & Wykonawca & Kompetencje \\
\hline Codzienna & Rewident & Pracownik fizyczny działu szybowego \\
\hline Tygodniowa & Sztygar z oddziału szybowego & Osoba ze średniego dozoru \\
\hline Sześciotygodniowa & $\begin{array}{l}\text { Dotyczy tylko i wyłącznie wyciągu szybowego, maszyny wyciągowej i lin (nie } \\
\text { dotyczy rury szybowej) }\end{array}$ & \\
\hline Kwartalna & Nadsztygar z oddziału szybowego & \\
\hline Roczna & Główny inżynier energomechaniczny & Kierownik działu energomechanicznego \\
\hline
\end{tabular}

Rewizja wykonywana jest z głowicy naczynia wyciągowego, na której zakłada się barierki i daszki ochronne. Pracownik zobowiązany jest do posiadania pełnego sprzętu wymaganego przez BHP.

\subsubsection{Monitoring wizyjny}

Monitoring wizualny oparty na kamerach cyfrowych jest stosowany w Polsce przez nieliczne firmy i instytucje. W 2014 roku jeden z najnowszych systemów został zaprojektowany przez Zespół Geodezji Górniczej Katedry Ochrony Terenów Górniczych, Geoinformatyki i Geodezji Górniczej Wydziału Geodezji Górniczej i Inżynierii Środowiska Akademii Górniczo-Hutniczej (Rys.1A - widok w laboratorium). System wymaga zainstalowania wyciągarki i systemu w świetle szybu. Następnie kapsuła opuszczana jest w dół za pomocą wyciągarki linowej. W kapsule znajdują się cztery kamery GoPro Hero 4 Black o parametrach nagrywania obrazu i wykonywania zdjęć klatkowych 4k (UltraHD) o szybkości do $60 \mathrm{klatek} / \mathrm{s}$ (obraz z kamery zaprezentowano na rysunku 2). Kamery ustawione prostopadle do siebie spoczywają na platformie wyposażonej w czujnik pochylenia, automatycznie poziomującej swoje ułożenie (Rys.1B - widok podczas pracy). Obraz oświetlany jest przez sześć reflektorów zamontowanych powyżej kamer.

a)

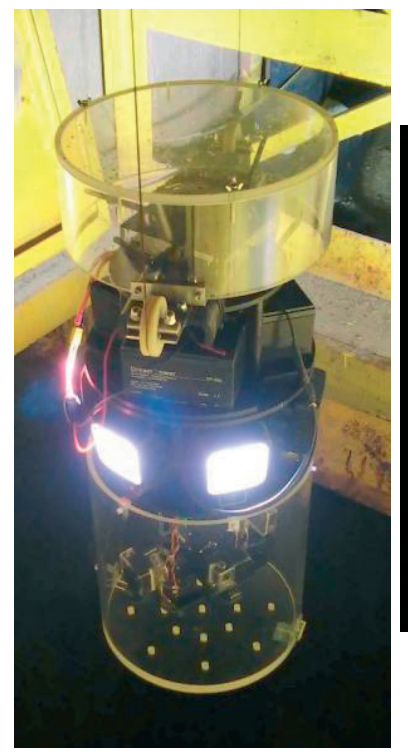

b)

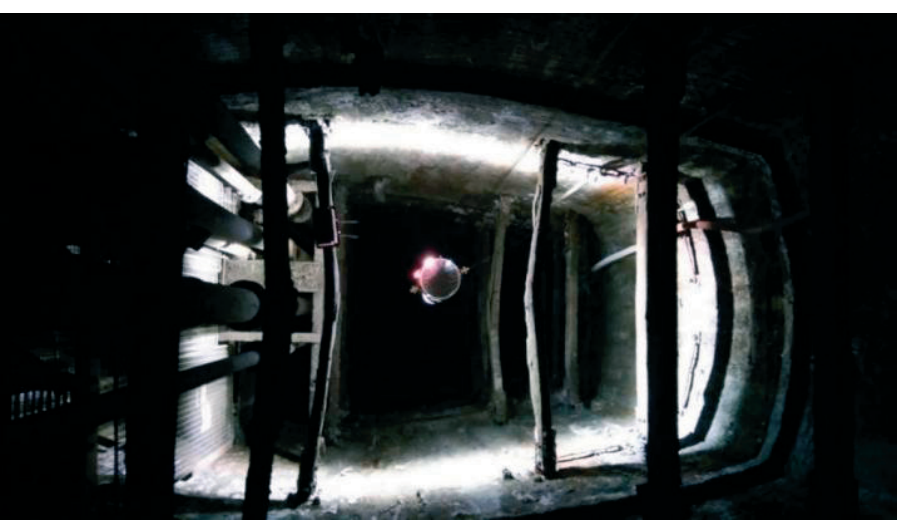

Rys. 1. System monitoringu wizyjnego: a) w laboratorium, b) podczas pracy w szybie 
Kapsuła zawiera również baterie zasilające kamery oraz anteny umożliwiające przekaz obrazu do komputera w czasie rzeczywistym. Daje to możliwość monitoringu aktualnie prowadzonych w szybie prac, np. wpływu iniekcji wykonywanych w celu uszczelnienia szybu na jego obudowę. Głębokość opuszczania systemu zależna jest jedynie od długości liny i możliwości wyciągarki.

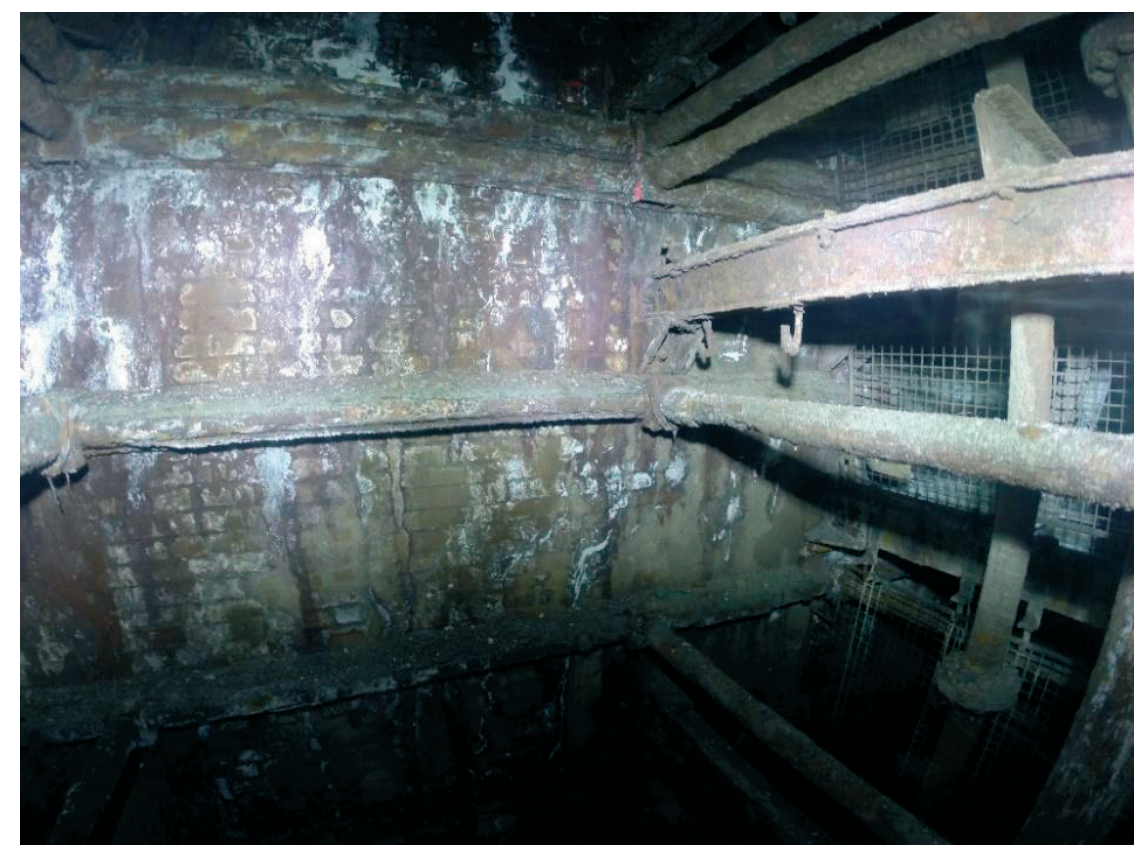

Rys. 2. Obraz z kamery systemu wizyjnego

Produktem z tak zaprojektowanego systemu jest nie tylko wizja i ocena stanu rury szybowej wraz z uzbrojeniem. Wstępnie przetworzone zdjęcia wprowadzić można do programów graficznych, a następnie wygenerować z nich metryczny trójwymiarowy model [5]. Może on stać się już przedmiotem analiz porównawczych z przejazdów w kolejnych seriach oraz podstawą do stworzenia modelu referencyjnego.

\subsection{Obserwacje metryczne}

Obserwacje metryczne to grupa metod pomiarowych rejestrujących jakościowoilościowy charakter zmian geometrii, struktury i fizyczno-mechanicznych parametrów elementów obudowy i uzbrojenia szybu. Badania tego typu wykonywane są nieregularnie, zwykle przez wyspecjalizowane przedsiębiorstwa lub instytucje. Zleceniodawcą takich badań mogą być władze górnicze lub osoby odpowiedzialne za bezpieczeństwo szybu. Badania specjalistyczne i pomiary geometrii szybu wykonywane są (w przypadku, kiedy w szybie nie obserwuje się znaczących zmian) raz na 5 lat. Zaś w przypadku stwierdzenia negatywnych zmian, badania wykonuje się częściej - zależnie od stanu szybu. Zakłady KGHM Polska Miedź S.A. zobowiązane są natomiast do wykonania pomiarów metrycznych po każdym silnym wstrząsie górniczym. Naturalnym jest więc dążenie do maksymalnego skrócenia czasu wyłączenia szybu na czas pomiarów. Wśród metod określanych jako metryczne w kontekście inwentaryzacji rury szybowej należy wyszczególnić kilka rodzajów pomiarów. Jako pierwsze wymienić należy klasyczne pomiary sytuacyjne i wysoko- 
ściowe w odniesieniu do punktów pomiarowych wyznaczanych na podstawie pionów mechanicznych i laserowych (w tym pomiary wysokościowych). Kolejnymi metodami są skaning laserowy 2D i 3D oraz obserwacje prowadzone z wykorzystaniem czujników zmian długości i pochyłomierzy.

\subsubsection{Punkty pomiarowe wyznaczane na podstawie pionów mechanicznych i laserowych}

Najczęściej wykonywane przy badaniu odkształceń poziomych rury szybowej jest wyznaczenie współrzędnych punktów pomiarowych na podstawie pionów mechanicznych lub laserowych. Piony o znanych współrzędnych, zwieszone w szybie (skierowane w płaszczyźnie pionowej lub o zadanym kącie) stanowią bazę pomiarową (osnowę) dla wyznaczania zmian sytuacyjnych na każdym kolejnym wyznaczanym profilu. Punkty kontrolne (zastabilizowane w obudowie lub charakterystyczne), wyznacza się na podstawie domiarów do pionów lub poprzez wykorzystanie pionów jako osnowy dla pomiarów tachymetrycznych (Rys. 3). W takim wypadku często wykonuje się jednocześnie cały profil zadanego horyzontu, mierząc nie tylko punkty kontrolne, ale również obudowę i elementy uzbrojenia szybu [6].

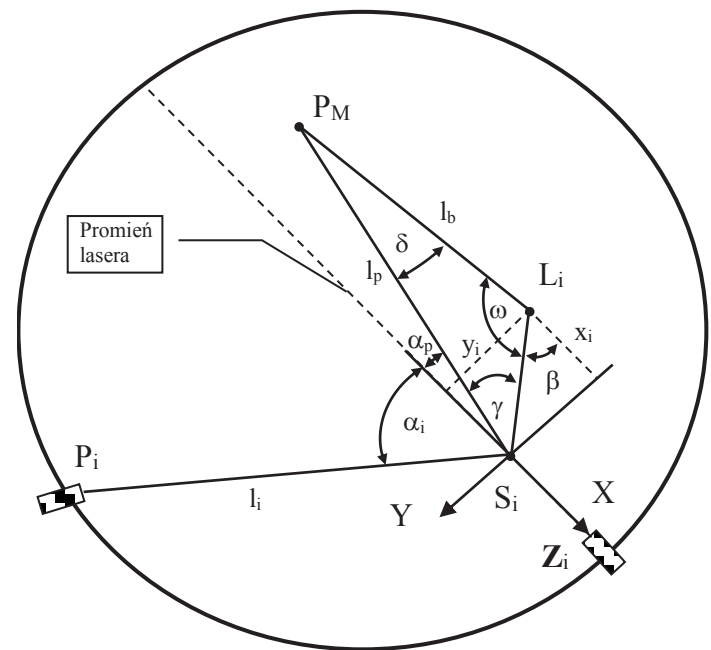

Rys. 3. Schemat pomiaru tachymetrycznego z wykorzystaniem pionów o wyznaczonych współrzędnych. $P_{M}, L_{i}$ - piony o wyznaczonych współrzędnych, $S_{i}$ - stanowisko pomiarowe, $P_{i}, Z_{i}$-punkty kontrolne $\alpha, \beta, \gamma, \delta, \omega$ - mierzone kąty [6]

W optymalnej wersji punkty są zastabilizowane w obudowie szybu, stanowiąc pionowe i poziome horyzonty obserwacyjne, tzw. linie pomiarowe. Poziome horyzonty powinny być rozmieszczone równomiernie na całej długości szybu lub odcinku podlegającym specjalnym obserwacjom (np. prowadzonym w utworach solnych). Interwał rozmieszczenia horyzontów powinien być zależny od zachodzących w szybie zjawisk, a pomiar przemieszczeń pionowych powinien odbywać się na podstawie pomiaru tych samych punktów. Realizuje się go różnie, w zależności od posiadanego przez zakład górniczy sprzętu pomiarowego oraz przyjętej metodologii. Zasadniczym zagadnieniem jest zawsze pomiar odległości pomiędzy punktami na kolejnych horyzontach. W podstawowej wersji do pomiaru wykorzystuje się ruletkę stalową zwieszoną w świetle szybu, wzdłuż linii pomiarowej (Rys. 4A). Bardziej nowoczesną wersją jest wykorzystanie dalmierzy laserowych lub elektroop- 
tycznych i reflektorów (stosowanych w zależności od zakładu w różnych konfiguracjach ustawienia) oraz niwelatora do pomiaru przewyższeń na dachu klatki szybowej i na podszybiu (Rys. 4B).

a)

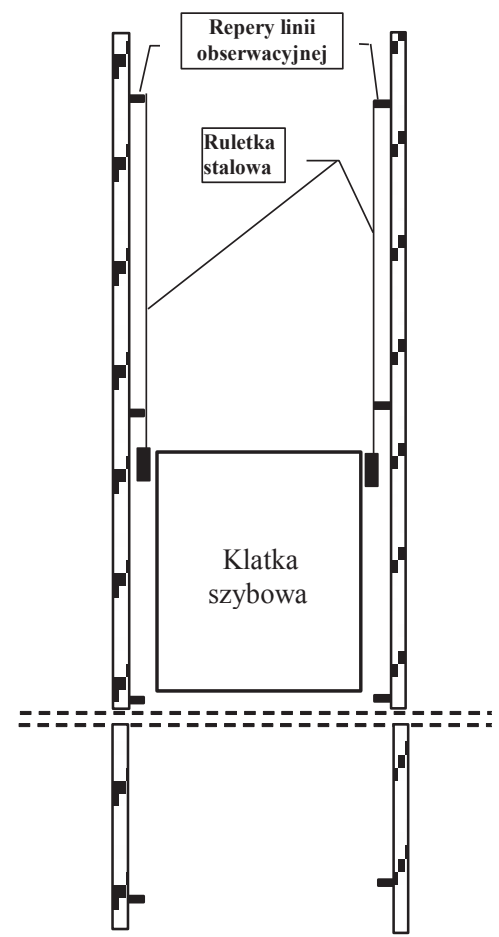

b)

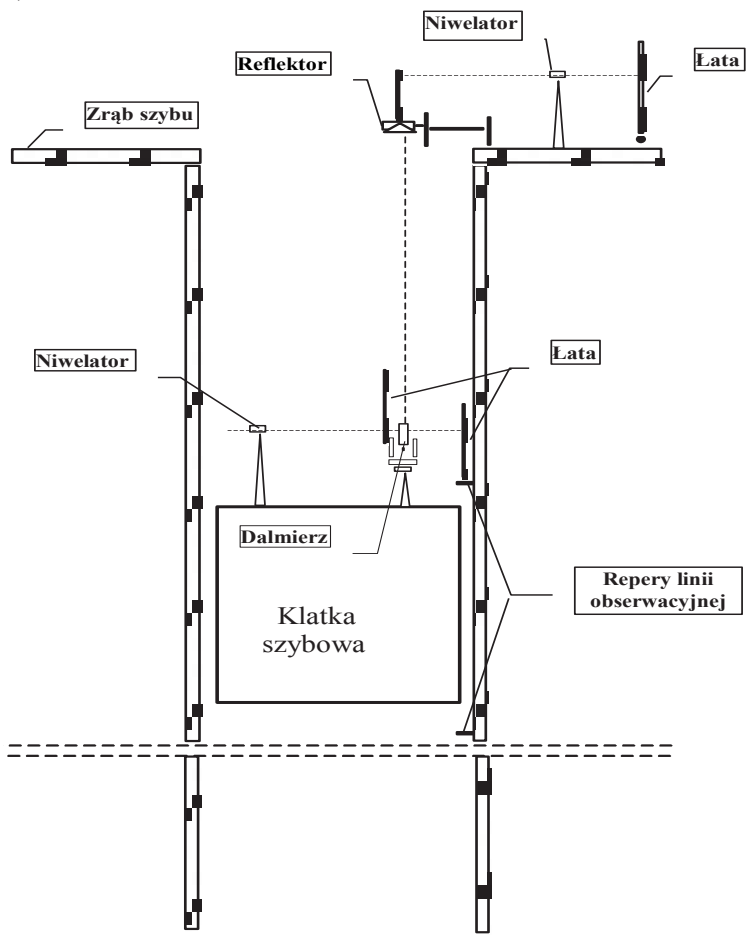

Rys. 4. Pomiar wysokościowy wykonywany przy wykorzystaniu: a) ruletki stalowej, b) dalmierza, reflektora i niwelatora [6]

Metodą pomiarową łączącą powyższe dwie (pomiar zmian sytuacyjnych i wysokościowych) jest wykorzystanie dalmierza laserowego i wideodetekcji plamki laserowej. W połączeniu $\mathrm{z}$ komputerowym systemem detekcji wiązki laserowej po przyłożeniu matrycy w ustalony sposób do zastabilizowanego punktu pomiarowego istnieje możliwość wykrywania zmian poziomych, a dalmierz mierzy odległość pionową [7].

\subsubsection{Skaning laserowy $2 D$ i $3 D$}

Skaning laserowy to metoda powszechnie stosowana do odwzorowania obiektów w prawie wszystkich dziedzinach. W kontekście badań szybowych wykonanie skaningu odbywa się z dachu klatki szybowej lub z wysięgników umieszczanych w przedziale drabinowym. Istnieje możliwość wykonania pomiarów skanerem 2D lub 3D. Skaner 2D w wersji stworzonej w Zespole Geodezji Górniczej stanowi połączenie dalmierza DISTO plus z silnikiem krokowym sterowanym za pomocą komputera (Rys. 5A). Umożliwia wykonanie profili poziomych, pionowych lub w dowolnie nachylonej płaszczyźnie. Synchronizacja czasów obrotu z momentem wykonywania pomiaru odległości daje możliwość uzyskania współrzędnych lokalnych w płaszczyźnie skanowania oraz późniejsze analizy i generowanie przekrojów w przestrzeni CAD (Rys. 5B) [7]. 
a)

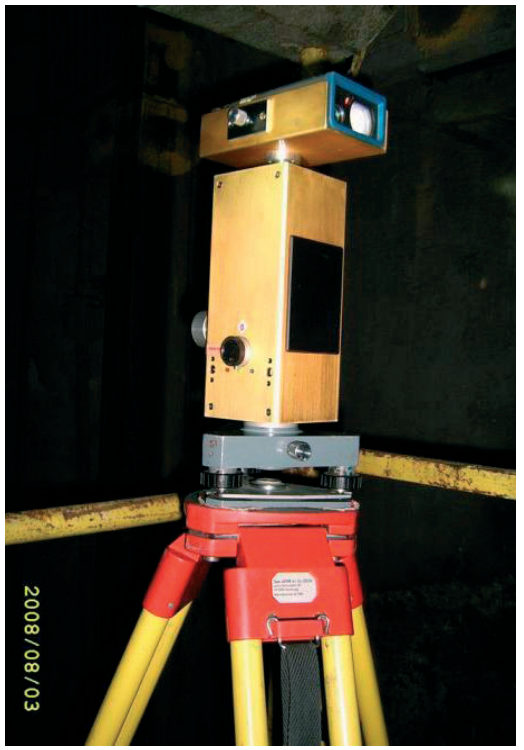

b)

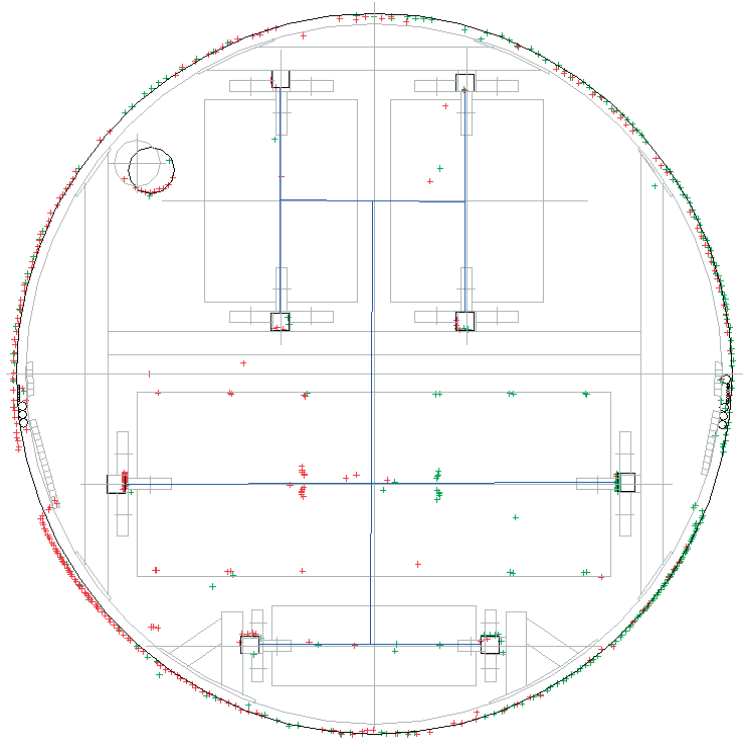

Rys. 5. a) Skaner laserowy 2D ustawiony na głowicy klatki szybowej, b) punkty profilowe uzyskane z pomiarów wykonanych za pomocą dwóch skanerów laserowych 2D na tle szkicu tarczy szybu [7]
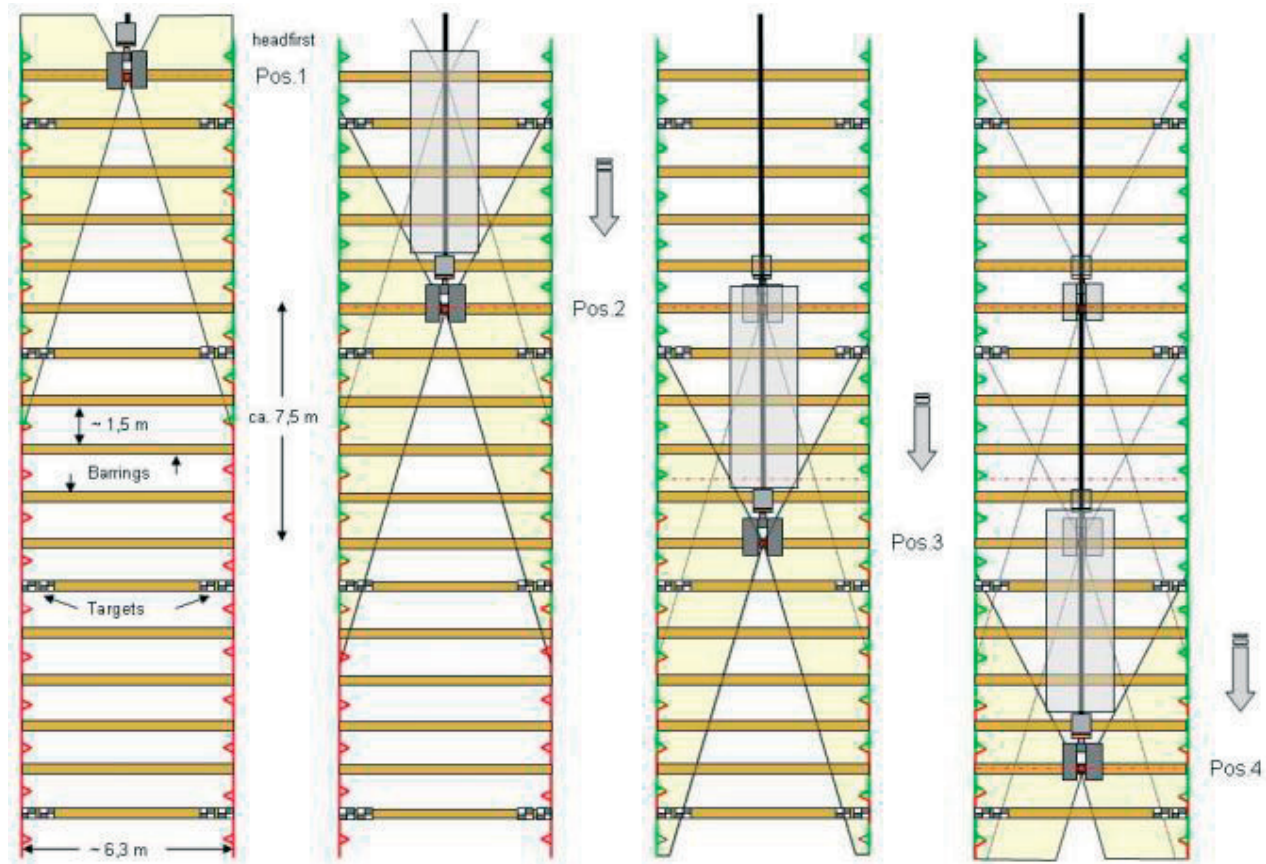

Rys. 6. Schemat prowadzenia pomiarów z wykorzystaniem skanera usytuowanego pionowo pod klatką szybową [8]

Skaner 3D wykonuje natomiast pomiar całości otaczającej przestrzeni, nadając wszystkim punktom w zadanej siatce pomiarowej współrzędne (X, Y, Z) oraz intensywność 
odbicia wiązki laserowej (tzw. Intensity - I). Trudność w pomiarach skaningowych zaczyna się już na etapie markowania (instalowania) punktów łącznych w szybach, które powinny być widoczne z sąsiednich stanowisk skanera. Stąd też pojawiają się koncepcje skanowania panoramicznego poprzez podwieszony pod naczyniem wyciągowym skaner, wykonujący pomiar na zasadzie zaprezentowanej na rysunku 6 lub polskie rozwiązania umieszczania skanera na dachu klatki [8]. Do łączenia kolejnych skanów wykorzystuje się punkty charakterystyczne identyfikowane w przestrzeni rury szybowej i elementów uzbrojenia lub stosuje się metodę wpasowania chmury w chmurę ( $\mathrm{z}$ ang. Cloud to cloud) [3].

\subsubsection{Czujniki zmian dlugości i pochyłomierze}

W przeciwieństwie do wyżej wymienionych metod czujniki zmian długości oraz pochyłomierze umożliwiają quasi-ciągły pomiar zmian zachodzących w szybie. Dzięki pomiarowi w dopasowanych do prędkości zachodzącego zjawiska interwałach istnieje możliwość bieżącego monitoringu zachodzących procesów. Technologia ta jest dedykowana szczególnie dla obiektów, w których bezpośrednim otoczeniu lub w nich samych są prowadzone prace mogące powodować nagłe zmiany. Już minimalne zmiany prezentujące pewien trend, wykryte odpowiednio wcześnie mogą zapobiec powstaniu uszkodzeń konstrukcji szybu oraz awarii krytycznych.

Oprócz ciągłego monitoringu stanu szybu, pomiary przy wykorzystaniu tensometrów, pochyłomierzy i szeroko pojętych metod telemetrycznych, nie wymagają bezpośredniego, każdorazowego uczestnictwa człowieka w pomiarach. Zmniejsza się też czas i liczba uciążliwych oraz kosztownych dla kopalni wyłączeń szybu z pracy.

\section{Zastosowanie systemu zbudowanego na bazie czujników zmian długości i pochyłomierzy. Monitoring geodezyjny w szybie Kościuszko KS Wieliczka}

W 2014 roku na potrzeby obserwacji szybu Kościuszko Kopalni Soli Wieliczka, podczas wykonywanych prac wiertniczych i iniekcyjnych, został zaprojektowany system geodezyjnego monitoringu deformacji obudowy szybu i kanału dolotowego oraz konstrukcji wieży szybowej. XVIII-wieczny szyb wydechowy przez stulecia był narażony na niszczące działanie soli wydobywającej się z powietrzem i parą wodną z kopalni. Ponadto wody powierzchniowe zalewały górną część jego obudowy i wdzierały się przez mikropęknięcia do środka [9].

\subsection{Projekt iniekcji}

W celu ograniczenia napływu wód zdecydowano o wykonaniu szeregu iniekcji wokół rury szybowej (Rys. 7). W pierwszym etapie od sierpnia 2014 roku wykonano 54 iniekcje strumieniowe w technologii Jet-grouting. Następnie w drugim etapie zagęszczono odwierty i do końca kwietnia 2015 roku wykonano dodatkowe 38 iniekcji w technologii łączonej: Jet-grouting i klasycznej. Średnia głębokość odwiertów wynosiła $15 \mathrm{~m}$. Technologia Jetgrouting polega na wywierceniu otworu i rozluźnieniu struktury gruntu przy pomocy powietrza oraz wody wtłaczanych pod dużym ciśnieniem. Następnie od najniższego punktu otworu wprowadza się pod dużym ciśnieniem (w opisywanym przypadku 20-25 MPa) mieszankę żywicy i cementu, która miesza się z gruntem. W czasie jej wprowadzania głowica obraca się ze stałą prędkością (22-125 obrotów na minutę). W efekcie wykonanych iniekcji powstał płaszcz wzmacniający konstrukcję rury szybowej i chroniący szyb przed napływem wód powierzchniowych. 


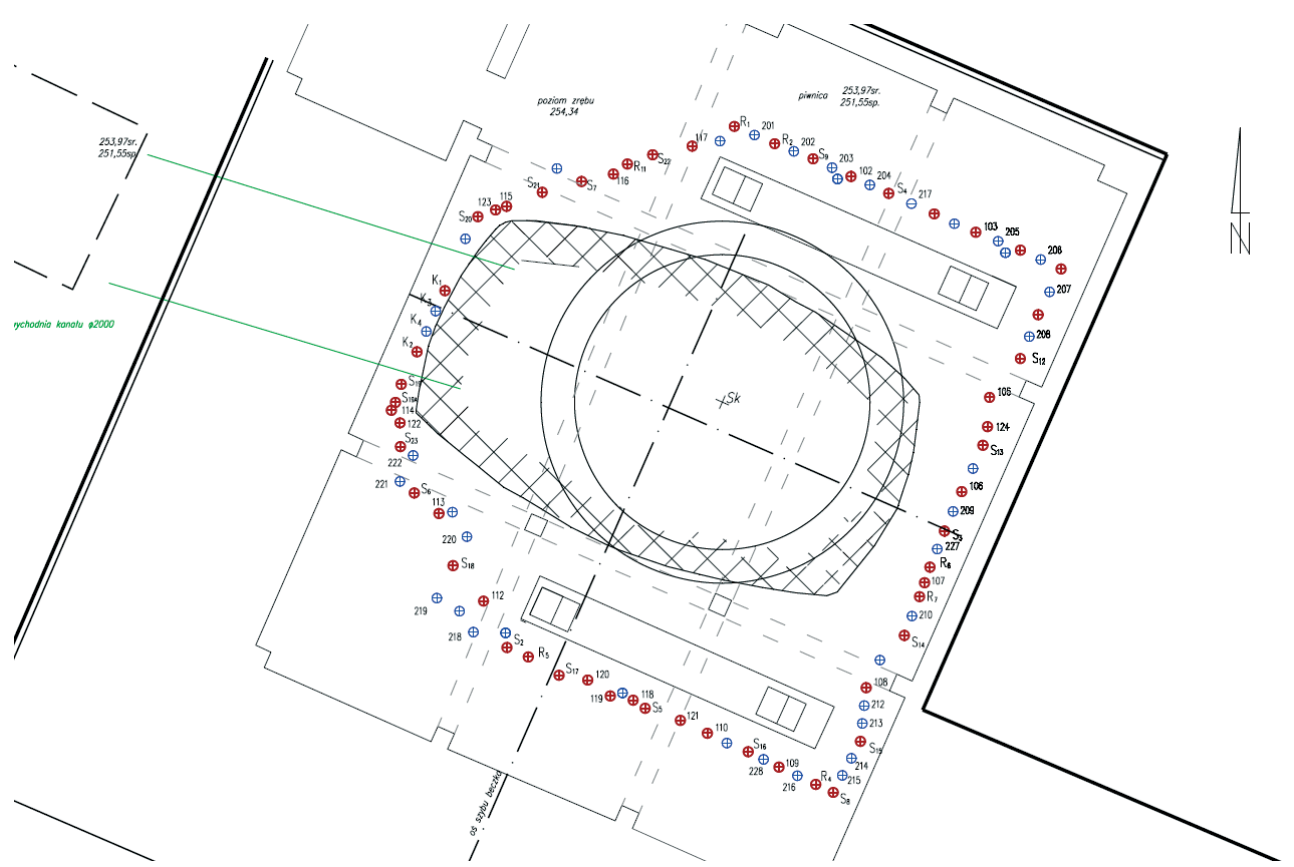

Rys. 7. Szkic budynku nadszybia, rury szybowej oraz wykonanych iniekcji w podziale na dwie fazy projektu (kolorem niebieskim oznaczono fazę 1, kolorem czerwonym - fazę 2) [9]

\subsection{Schemat rozmieszczenia czujników}

Na podstawie wykonanych analiz zdecydowano o instalacji czujników na pięciu poziomych horyzontach pomiarowych oraz czujników zmian długości pionowej pomiędzy kolejnymi horyzontami. Pomiędzy zastrzałami wieży szybowej zainstalowano czujnik zmian długości (Rys. 8).

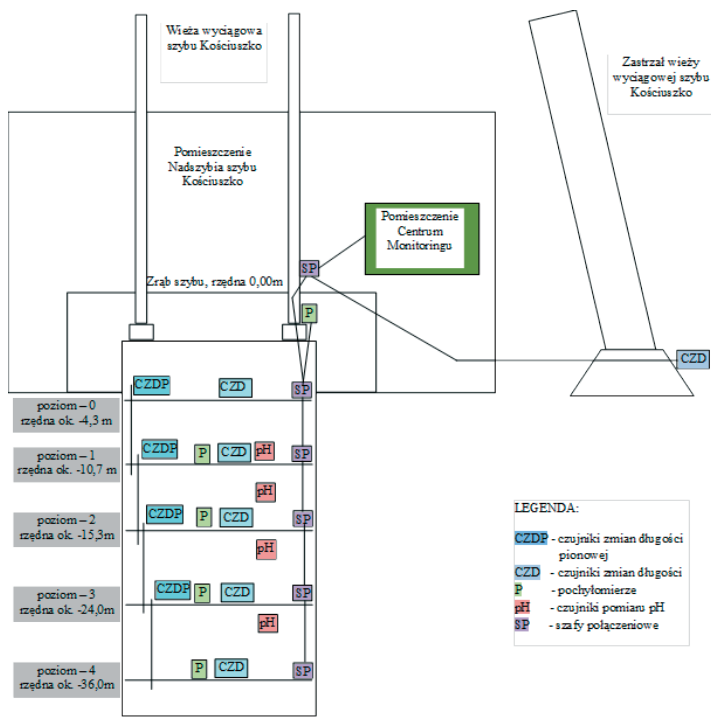

Rys. 8. Schemat rozmieszczenia elementów systemu monitoringu w szybie Kościuszko [9] 
Na poszczególnych poziomach umieszczono dwie prostopadłe do siebie bazy tensometryczne (potencjonometry rezystancyjne o dokładności pomiaru $0,1 \mathrm{~mm}$ ), pochyłomierze (Nivel 220 firmy Leica o rozdzielczości $0,01 \mathrm{~mm} / \mathrm{m}$ ) oraz czujniki pomiaru pH wody w zakresie 6-14. Czujniki umieszczono w taki sposób, aby umożliwić przejazd kolumną z systemem wizyjnym. Pomiar temperatury na każdym poziomie oraz na zastrzałach wieży szybowej umożliwił późniejsze wprowadzenie poprawek termicznych. Obserwacje z czujników zbierane były najpierw w szafach połączeniowych na poszczególnych poziomach, a następnie przekazywane kablami wielożyłowymi do centrum monitoringu w nadszybiu. Obserwator, zbierając dane w czasie rzeczywistym, mógł w każdej chwili zadecydować o zatrzymaniu wykonywania iniekcji lub korekcie projektu (zmiana prędkości podnoszenia głowicy czy zmiana ciśnienia podawania iniektu).

\subsection{Opracowanie danych i analiza}

Dane otrzymywane początkowo w voltach autorski program oparty o środowisko LabView przeliczał na jednostki metryczne i stopnie Celsjusza. Oprócz monitoringu bieżącego, po opracowaniu danych, wykonano analizy zachowania szybu pod wpływem iniekcji wykonywanych w jego bezpośrednim sąsiedztwie oraz stworzono zestawienie całkowitych zmian długości (Tab. 2 i 3 ).

Tabela 2. Zmiany długości cięgien poziomych [9]

\begin{tabular}{cccccccccccc}
\hline \multirow{2}{*}{$\begin{array}{c}\text { poziom } \\
\text { / data }\end{array}$} & \multicolumn{4}{c}{ W-E (podłużne) $[\mathrm{mm}]$} \\
\cline { 2 - 11 } & $11.08-$ & $16.09-$ & $12.11-$ & $16.01-$ & zmiany & $11.08-$ & $16.09-$ & $12.11-$ & $16.01-$ & zmiany \\
& 15.09 & 16.10 & 20.11 & 17.03 & calkowite & 15.09 & 16.10 & 20.11 & 17.03 & calkowite \\
\hline 0 & 1,45 & $-0,90$ & 0,18 & 0,00 & $\mathbf{0 , 7 3}$ & 0,63 & 0,01 & 0,30 & 0,08 & $\mathbf{1 , 0 2}$ \\
1 & 0,58 & 1,35 & 0,22 & 1,62 & $\mathbf{3 , 7 7}$ & $-0,80$ & $-1,20$ & 0,10 & $-2,80$ & $\mathbf{- 4 , 8 0}$ \\
2 & 0,25 & 1,30 & 0,06 & 2,14 & $\mathbf{3 , 7 5}$ & $-3,30$ & $-4,10$ & 0,02 & 0,02 & $\mathbf{- 7 , 4 0}$ \\
3 & $-0,10$ & 0,05 & 0,14 & 1,13 & $\mathbf{1 , 1 8}$ & 0,32 & 0,17 & 0,08 & 0,17 & $\mathbf{0 , 7 4}$ \\
4 & 0,42 & $-0,10$ & 0,12 & $-0,20$ & $\mathbf{0 , 3 1}$ & 1,32 & 0,00 & 0,22 & 0,15 & $\mathbf{1 , 6 9}$ \\
\hline
\end{tabular}

Tabela 3. Zmiany długości cięgien pionowych [9]

\begin{tabular}{cccccc}
\hline $\begin{array}{c}\text { poziom } \\
\text { / data }\end{array}$ & $11.08-15.09$ & $16.09-16.10$ & $12.11-20.11$ & $16.01-17.03$ & Calkowite [mm] \\
\hline $0-1$ & 0,42 & $-0,20$ & 0,27 & 0,30 & $\mathbf{0 , 8 2}$ \\
$1-2$ & 0,28 & 0,18 & 0,08 & 1,23 & $\mathbf{1 , 7 7}$ \\
$2-3$ & $-1,20$ & $-10,00$ & $-1,80$ & $-0,20$ & $\mathbf{- 1 3 , 0 0}$ \\
$3-4$ & 0,10 & 0,00 & 0,00 & 0,00 & $\mathbf{0 , 0 9}$ \\
\hline
\end{tabular}

Analiza wykazała, że najbardziej narażone na działanie iniekcji były poziomy znajdujące się w pobliżu średniej głębokości wykonywanych iniekcji $(15 \mathrm{~m})$. Największe zmiany poziome zaobserwowano więc na poziomie 2 (na głębokości 15,2 m), a największa zmiana długości pionowej ujawniła się pomiędzy poziomami 2 a 3. Dla lepszej prezentacji wyników zmiany długości na podstawie znanych długości cięgien przeliczono na deformacje $\mathrm{W} \mathrm{mm} / \mathrm{m}$ i zestawiono $\mathrm{w}$ tabeli 4.

Na podstawie danych zebranych dla rozstawu zastrzałów wieży szybowej, zredukowanych o poprawkę termiczną, stwierdzono brak większych zmian (w granicach $0,1 \mathrm{~mm} / \mathrm{m}$ na przestrzeni całych badań). 
Tabela 5. Deformacje całkowite cięgien poziomych i pionowych [9]

\begin{tabular}{|c|c|c|c|c|c|}
\hline \multicolumn{3}{|c|}{ profile poziome $[\mathrm{mm} / \mathrm{m}]$} & \multicolumn{3}{|c|}{ profile pionowe } \\
\hline poziom & $\begin{array}{c}\text { W-E (podłużne) } \\
5,9 \mathrm{~m}\end{array}$ & $\begin{array}{c}\mathrm{N}-\mathrm{S} \text { (poprzeczne) } \\
4,4 \mathrm{~m}\end{array}$ & poziom & długość cięgna & deformacje \\
\hline 0 & 0,12 & 0,23 & & {$[\mathrm{~m}]$} & {$[\mathrm{mm} / \mathrm{m}]$} \\
\hline 1 & 0,64 & $-1,08$ & $0-1$ & 6,4 & 0,13 \\
\hline 2 & 0,64 & $-1,68$ & $1-2$ & 4,6 & 0,38 \\
\hline 3 & 0,20 & 0,17 & $2-3$ & 8,7 & $-1,52$ \\
\hline 4 & 0,05 & 0,38 & $3-4$ & 12,0 & 0,01 \\
\hline
\end{tabular}

\section{Podsumowanie}

Szyb górniczy jest poddawany szeregowi inspekcji i pomiarów. Obserwacje - zarówno ocena wizualna, jak i pomiary metryczne - prowadzone są w określonym interwale czasowym. Wykazują więc jedynie stan obiektu w momencie jego obserwacji, uniemożliwiając $\mathrm{w}$ ten sposób analizę w kontekście przyczyn zaistniałych zmian. Natomiast tylko poznanie przyczyn procesów zachodzących w szybie może uchronić go przed awariami krytycznymi.

Dzięki systemowi zaprezentowanemu w ostatniej części artykułu wykonano analizę procesów zachodzących w szybie przy wykonywaniu iniekcji uszczelniających. Uzyskane wyniki pracy systemu są w pełni zadowalające. Dla prac mogących mieć wpływ na bezpieczeństwo szybu (np. pogłębianie czy zalewanie szybu, eksploatacja w filarze ochronnym czy wykonywanie iniekcji) rekomenduje się wykorzystanie ciągłego monitoringu. Należy rozważyć ekonomiczny aspekt instalacji systemów w szybach podlegających obowiązkowym pomiarom kontrolnym po tąpnięciach oraz odcinkom szybów poprowadzonych w utworach solnych i podlegających ciągłym deformacjom.

Zmniejszenie liczby pomiarów wykonywanych w szybie podnosi bezpieczeństwo pomiarowych, a ciągła obserwacja rury szybowej umożliwia ocenę konieczności wykonania geodezyjnych pomiarów kontrolnych. W sytuacjach krytycznych system może zaalarmować dział szybowy o niebezpiecznych zmianach. Ponadto analiza metod uważanych za klasyczne wskazuje, że metody ciągłych pomiarów telemetrycznych w rurach szybowych dają możliwość zastąpienia niektórych okresowych pomiarów inwentaryzacyjnych i kontrolnych.

Artykut jest opracowaniem referatu z Konferencji Naukowo-Technicznej „Współczesne problemy geodezji i ochrony środowiska” organizowanej na Uniwersytecie Przyrodniczym $w$ Lublinie.

System wraz z oprogramowaniem integrujacym dane monitoringu zbudowano $w$ ramach projektu: „, Opracowanie technologii uszczelniania szybów górniczych przez Kopalnię Soli ,Wieliczka”, wspólfinansowanego ze środków Europejskiego Funduszu Rozwoju Regionalnego i jest przedmiotem zgłoszenia patentowego.

Artykut opracowano w ramach prac statutowych AGH nr 11.11.150.195.

\section{Bibliografia}

1. Rozporządzenie Ministra Gospodarki z dnia 28 czerwca 2002 roku w sprawie bezpieczeństwa i higieny pracy, prowadzenia ruchu oraz specjalistycznego zabezpieczenia przeciwpożarowego w podziemnych zakładach górniczych, Dz.U.02.139.1169. 
2. Załącznik nr 4 do Rozporządzenia Ministra Gospodarki z dnia 28 czerwca 2002 roku [6] „Szczegółowe zasady prowadzenia ruchu w wyrobiskach”, Dz.U.02.139.1169.

3. Szczerbowski Z., Jóźwik M. Przykłady naturalnych i górniczych uwarunkowań deformacji szybów górniczych. XXV Zimowa Szkoła Mechaniki Górotworu 'Geotechnika i budownictwo specjalne', Zakopane, 2002.

4. Lipecki T. Kompleksowa ocena stanu geometrycznego obiektów i urządzeń szybowych z zastosowaniem skaningu laserowego. Wydawnictwa AGH, 2013.

5. Preuss R. Automatyzacja procesu przetwarzania danych obrazowych. Archiwum Fotogrametrii, Kartografii i Teledetekcji 26 (2014) 119-127.

6. Jóźwik M., Jaśkowski W. Wykorzystanie nowoczesnych technik pomiarowych do określania odksztatceń rury szybowej. Niepublikowany raport wykonany dla KGHM Polska Miedź S.A., 1999.

7. Jaśkowski W. Kompleksowe wyznaczanie geometrii szybów górniczych za pomoca Modularnego Systemu Pomiarowego. Wydawnictwa AGH, 2013.

8. Bock J., Uhl O., Benecke N., Kuchenbecker R. Support of high performance operations in coal mining by use of $3 d$ laser scanning. Camborne School of Mines IMS, Camborne School of Mines, 2009.

9. Jaśkowski W., Lipecki T., Jabłoński M. Deformacje szybu „Kościuszko” KS Wieliczka wywotane pracami uszczelniającymi obudowę szybu. Przegląd Górniczy 1(2016) 4-11.

\title{
The usage of telemetry measurements methods in order to determine shaft tube
}

\author{
Mateusz Jabłoński, Wojciech Jaśkowski \\ AGH University of Science and Technology, \\ Faculty of Mining Surveying and Environmental Engineering, \\ Department of Mine Areas Protection, Geoinformatics and Mine Surveying, \\ e-mail:jablon@agh.edu.pl,jaskow@agh.edu.pl
}

\begin{abstract}
Ensuring shaft's safe operation is the primary aim of measurements and observations performed in mining shafts. This involves not only determining the current technical condition of the mining shaft, but also determining causes of observed changes. In order to preserve the efficiency of every shafts several inventory works have been performed, described in details in Ordinance (Regulation of the Minister of Economy from $28^{\text {th }}$ of June 2002) and its appendix number 4 [1,2]. The report presents an overview of measurements techniques which are in use in order to perform shift tube's inventory, with particular emphasis on telemetric measurement methods.

As an example monitoring system designed for 'Kościuszko' shaft in 'Wieliczka' Salt Mine has been described in details. In order to prevent such situations, mobile system for monitoring the condition of the structure of the shaft was mounted and user in 2014 and 2015. Its indications allowed to define in the current time the value of deformation occurring in the shaft, and if necessary immediately modify the schedule and course of injection works. Analysis of the results shows a slight deformation of the shaft housing during the injection, and demonstrates the advantages of the monitoring system and a novel method of high-pressure injections.
\end{abstract}

Keywords: telemetry, shaft tube, inventory. 